\title{
Impacts of India’s Transit Warfare against Nepal
}

\author{
Bishnu Pathak ${ }^{1^{*}}$ \\ ${ }^{1}$ Commission of Investigation on Enforced Disappeared Persons, Kathmandu, Nepal \\ * Bishnu Pathak, E-mail: pathakbishnu@gmail.com
}

\begin{abstract}
Nepal promulgated the New Constitution with signatures of 90 percent of the Constituent Assembly (CA) II members on September 20, 2015. The world congratulated Nepal for its success, but Nepal's roji-roti-beti closest neighbor India sent a cold-note and a mild-warning. India informally conveyed a proposed 7-point constitutional amendment the following day supporting 10 percent of Nepal's CA II, which are agitating Madhesi groups. Such amendments interfere with landlocked Nepal's sovereign and internal affairs, but Nepal was full of confusion in answering it. Moreover, India initiated an undeclared transit trade warfare, blocking Nepo-India borders. The blocking at borders is freezing the life of all Nepalis. Now Nepal suffers from an acute shortage of cooking and oxygen gas, gasoline, medicines and other daily humanitarian supplies. Hospitals have stopped normal operations in the lack of medicines and oxygen gas. No gasoline is being provided to public and private vehicles except security officials. Only emergency flights are operating. Worse still, India's transit warfare was conducted in a period when Nepo-China borders were blocked by the post-Earthquake. India's proposed Amendment in the Constitution for Madhesi groups is just a drama; clearly the myopic interest of India is to control Nepal's natural resources and to restore the Hindu Kingdom. Ranjit Rae, India's Ambassador to Kathmandu gathering agitating Tarai-Madhes leaders into the Embassy just before Prime Minister's election said, "The winning of Oli ${ }^{i}$ as a Prime Minister of Nepal is a defeat of India” (Ratopati, 2015). Rae further hurts the Nepali as he followed Goebbels'style of reporting to New Delhi. As a result, angry masses are displaying arson effigies of India and PM Modi across the country ranging in Tarai, Hill and Mountain. The 21st century's great socialist leader Modi now becomes known as a bully leader in the eyes of Nepali and South Asian people. And his popularity is plummeting each and every day. If the talented and clever Modi does not abandon his ego and ambition, he might do suicide in the same way Nepal's former King Mahendra did in 1972 when he honestly realized the error of his past mistakes and wrongdoings. Nepal now turns to United Nations against India's shadow-boxing to achieve landlocked country's sovereign rights and other concerned rights.
\end{abstract}

\section{Keywords}

constitution, transit, warfare, blockade, madhesi and constituent assembly 


\section{Introduction}

"Big, strong and rich should not bully small, weak and poor"-Xi Jinping, President of China ${ }^{\mathrm{ii}}$.

While the Constituent Assembly (CA) II promulgated one of the most liberal New Constitutions in Nepal by nine-tenths of the elected representatives at 5.55 PM on September 20, 2015 Sunday, India unofficially initiated transit warfare against Nepal, blocking all custom checkpoints the following day. They are: Kakarvita (Panitanki), Biratnagar (Jogbani), Birgunj (Raxaul), Bhairahawa (Sunauli) and Nepalgunj (Rupaidia). Nepal heavily depends on supplies from neighboring India. The transit or trade blockade (threat of blockade) or warfare appears to be a power bargaining tool because of jealousy, emotion, ego and a superiority complex. Nepal's proclaimed Constitution, representing a sovereign, independent and landlocked country, ignores the myopic advices of so-called big brother, the bully, of India. Indeed, India has imposed an unofficial blockade over Nepal's new constitution. Yet India denies its imposition of blockade.

The crisis surprisingly came as India adopted three-pillar policies: first, support Kathmandu ruling elites, second, encourage the Hindu Kingdom and third, control Madhesi feudal leaders, all at one time ${ }^{\text {iii }}$. Thus, big III parties are not supportive enough towards Tarai-Madhes agitation and their demands because of India's full-fledge supports to them.

All walks of life are presently crippled in Nepal. There is no cooking and oxygen gas, no fuel for vehicles even in diplomatic missions, no turbine fuel, no essential daily commodities, no distribution of humanitarian supplies, no security of cargo vehicles and their staffs in India-bordering land, no factories/industries running, no print media working, no meal for daily wage laborers, no hotels to eat available to pedestrians, no schools for students, no medicines for serious parents and lives are about to freeze. International Policy Digest stated that a long column of transports carrying petroleum goods to foods and medicine are reported waiting at the Indian side of the border for five-week (Upol, 2015). Prices of daily essential commodities have skyrocketed across the country. Public frustration, emotion and anger are escalating over New Delhi's perceived interference in Nepal's internal affairs. Yet India is saying, "Madhesi protesters are in no-men's-land, blocking the roads at custom checkpoints, so loaded trucks are not being able to supply towards Nepal”, but this is not true. What is true is that India urges to initiate meaningful dialogue with their protected protesters to end the standoff of transit in Nepal.

The term "warfare" in this concept applies how a powerful state, being like big brother, bullies and imposes its myopic interest to suppress people's voices, livelihoods, and people's rights to life, liberty, security and dignity in the weaker state. In this context, warfare distorts the normal course of economic, socio-cultural, information and political system.

Sadly, warfare imitates Goebbels’ propaganda (Pathak, 2005). Propaganda is a principal tool of warfare that says one thing, but acts differently. This propaganda warfare falls under conspiracy and intervention theory. The weak, poor, small, but landlocked Nepal suffers in all-round dimensions while India imposes a deliberate transit blockade against Nepal, which was just celebrating promulgation of a new 2015 constitution.

Published by SCHOLINK INC. 
The Goebbels trend pursued by Ambassador Rae, External Intelligence Agency named Research and Analysis Wing (RAW) and Subrahmanyam Jaishankar and Abhay Thakur of Ministry of Foreign Affairs, New Delhi and PM Modi swung into action without further analysis, readings and reporting. India internationally denied that it was imposing a transit blockade against Nepal, but on October 3, 2015, India's Ministry of External Affairs instructed its customs officials to release stranded cargos to Nepal from its border (Nepali Times, 2015). Despite this, hurdles continue to block import of petroleum products and daily essentials from India into Nepal (Kathmandu Post, 2015). The instruction came just as Nepal's land-route to China opened, clearing the post-earthquake debris from the road.

The principal objective of this study is to tell the truth across the globe about what is going on after the promulgation of Nepal's constitution. It gives a clear picture of Madhesi agitation and their demands, India's short-sighted-love with Madhesis only ${ }^{\text {iv }}$ and the stand of three mainstream political parties, reasons behind the initiation of transit warfare, landlocked countries' rights, and others. The paper follows primary, secondary and tertiary information. Required information was gathered through networking tracking methods or snowball techniques. The article is prepared based upon a practical observation approach rather than pursuing theoretical perception. The analyses are mostly drawn from yesterday's learning, experiencing difficulties today and hope for tomorrow. India, herewith, generally refers to the Government of India and its permanent Government called bureaucrats, but not people of diverse professions there.

\section{Constitutional Provisions}

Nepal's 7-decade long, cherished dream of writing its $7 \mathrm{th}^{\mathrm{v}}$ New Constitution through an elected congress of people, finally came true on September 20, 2015, when the President officially promulgated it as a Federal Democratic Republic with secular Nepal amidst a grand ceremony organized in the Constituent Assembly (CA) II hall. Ninety percent of the people's representatives out of 597 assembly members signed the Constitution. After promulgating the Constitution, the CA II dissolved and turned into the Legislative Parliament.

The Preamble opens with, "We, the people of Nepal..." The Preamble embraces the right to autonomy and self-rule by the people, stating Nepal is an independent, sovereign country with geographical integrity, national unity, freedom and dignity. It ends all forms of discrimination created by the feudal, autocratic, centralized and unitary system, but now respects multi-caste, multi-lingual, multi-cultural and geographical diversities. It firmly opposes class, caste/ethnicity, region, language, and religion and gender discrimination. However, it protects and promotes unity in diversity, social and cultural solidarity, tolerance and harmony. The Preamble aims to create an egalitarian society based on the principles of proportional inclusion, participation, equitable economy and social justice. It advocates ensuring socialism adopting peoples' competitive multi-party democratic governance system, civil liberty, fundamental human rights, adult franchise, periodic elections, complete press freedom and an independent, impartial and competent judiciary and the concept of the rule of law. 
A few of the salient features of new constitution are: preamble as a People's Constitution; federal republican as fundamental principle; seven-province federal division; provision for no-confidence motion against the PM for two years; in case the PM fails to win the trust-vote, president shall dissolve the parliament and declare a date of fresh elections within six-months, but PM cannot dissolve the parliament; mixed electoral system with reservations for underprivileged groups; president and vice-president to be different in terms of gender and community; one either (speaker or deputy speaker) to be a woman; inclusive Cabinet with maximum of 25 members; separate Constitutional Commission each of Madhesis, Dalits, Janjatis, Tharus, Muslims and women; all languages spoken in Nepal as national languages; separate rights for center, provinces and local bodies; flexible provisions regarding citizenship and separate fundamental rights to health, food, housing, children, dalits, women; and social security and justice ${ }^{\mathrm{vi}}$.

\section{Celebration}

People celebrated the Constitution proclamation day by carrying out welcome rallies with flags across Nepal. The CA II hall was magnificently decorated with national flags, flowers, lights and festoons (Nepali Times, 2015). Sporadic fireworks lit up the sky in the front side of the CA II hall after the constitution was promulgated. Thousands of euphoric people marched through the streets and many of them gathered outside the CA II hall to celebrate the much-awaited promulgation of a new constitution. Many of them were swaying flags by their hands and exchanging greetings with each other. Some of the young people painted the national flag on their faces. A few of them sang a song of national anthem while shouting, saying "Nepal! Nepal!! ...” Many houses and buildings were lit up with butter and oil lamps and fancy electric lights in all major cities. People believed that promulgation of a new constitution was a logical conclusion to the transitional justice which began along with 12-point understanding in November $2005^{\text {vii }}$. A wide range of people of all professions celebrated the promulgation as a first-ever Constitution written by the People's Representatives, lighting candles, oil lamps, drawing Nepal's flags and maps in every crossroad and in communities. The Government appealed to all to illuminate their residences and declared a two-day holidays to celebrate the momentous occasion. At the same time, a statute was protested in a few of the Tarai-Madhes districts such as Saptari, Mahottari (Himalayan Times, 2015).

\section{Welcome}

On Behalf of the Government of India, its Minister of External Affairs sadly said, "Throughout the process of Constitution-making in Nepal, India has supported a federal, democratic, republican and inclusive Constitution. We note the promulgation in Nepal on Sunday of a Constitution" (Indian Express, 2015). The Ministry further said, "We are concerned that the situation in several parts of the country bordering India continues to be violent. Our Ambassador in Kathmandu has spoken to the Prime Minister of Nepal in this regard”. Indian Foreign Secretary S. Jaishankar, who visited September 
18 to 19 in Kathmandu as a special envoy of PM Narendra Modi, had conveyed similar messages to the leaders of Nepal.

US State Department spokesperson John Kirby congratulated the people of Nepal on their persistent commitment to democracy. He said, "The promulgation of the constitution is an important milestone in Nepal's democratic journey”. He further stated that the constitution embraces measures consistent with globally accepted norms and principles, including gender equality, religious freedom, and the right to citizenship. He argued, "We encourage all Nepalis to continue to engage in the democratic process through peaceful, nonviolent means” (US Department of State, 2015).

During a dinner reception hosted by US President Barack Obama on September 29, 2015 in honor of the head of the states and delegates taking part in the 70th session of the UN General Assembly in New York, he congratulated Nepal and Nepali people for the promulgation of the new constitution (Eherald post, 2015).

The following day of constitution promulgation, Chinese Foreign Ministry spokesperson Hong Lei sincerely congratulated Nepal in the hope that the country would take this opportunity to realize national unity, stability and development. He said "China attaches great importance to relations with Nepal, and stands ready to further deepen bilateral friendly cooperation and provide assistance for Nepal's economic and social development to the best of her capacity” (Kathmandu Post, 2015).

On September 27, 2015, addressing the ongoing 70th session of the United Nations General Assembly, Chinese President Xi Jinping said, "Big, strong and rich should not bully the small, weak and poor", nations without mentioning the current problems faced by Nepal. He stressed rejection of an outdated mindset that one gain means the other's loss, or winner takes all (The New York Times, 2015). He further said, "China will never pursue hegemony, expansion or spheres of influence”. Mr. Xi said, "The principle of sovereign equality underpins the UN Charter. The future of the world must be shaped by all countries. All countries are equals". He, speaking for the first time in the UNGA, further said, "The principle of sovereignty not only means that the sovereignty and territorial integrity of all countries are inviolable and their internal affairs are not subjected to interference”. He focused on mutual respect as win-win cooperation on the course to handling their relations without conflict and confrontation. He stated, "Big countries should treat small countries as equals, and take a right approach to justice and interests by putting justice before interests” (Kathmandu Post, 2015). China supplied 1,000 metric tones of gasoline in grant early November 2015 (Ghimire, 2015).

German Foreign Minister Frank Walter Steinmeier welcomed the promulgation of the new constitution, saying. "This is an important step toward reconciliation and further democracy. Nepal is entering a new chapter in its history and is now a country with a democratic constitution", He further said, "I am hopeful that the violent unrests which have erupted these past weeks, especially in the Tarai region, will be resolved through dialogue between demonstrators and the government, and that the inclusion of all nationalities be continued” (Republica, 2015).

A few days before the Constitution promulgation, UK Minister for Asia, Hugo Swire, welcomed the Published by SCHOLINK INC. 
progress made by Nepal over the last few months toward the adoption of a new constitution. Swire said, "We hope that the new constitution will be inclusive, broadly supported and meet international standards of equality and respect for human rights, and lay the foundations of stability and prosperity as Nepal continues to rebuild following the devastating earthquake on 25th April” (Republica, 2015).

The French Foreign Ministry through statement said, "France welcomes the promulgation of the new constitution by Nepal, which therefore completes the political process initiated in 2008”. His spokesperson also quoted that the constitution is a key step toward continuing national reconciliation, restoring political stability and returning to the path of development (Republica, 2015).

The office of UN Secretary-General Ban Ki-moon issued a rather terse statement on the adoption of the constitution that merely "acknowledged" and without any congratulatory warmth (Gautam, 2015) on September 21, 2015. Within four days, though, the UN issued a second statement, with Ban Ki-moon "commending the Nepali people on the adoption of the new constitution" calling it "a milestone in the peace process”. The second UN statement, by his spokesperson Stéphane Dujarric, seems more accurate, realistic and balanced. Indeed, this statement has commended the spirit of all Nepali people. Nepal's development partners welcomed the Constitution. Swiss Ambassador to Nepal Urs Harren on behalf of all donor agencies said, "Promulgation of a new constitution has closed the chapter of the peace process in the country (Himalayan Times, 2015)”. Besides, Harren mentioned that they are fully aware of the problems Nepal faced during delivery of the Constitution.

Pakistan, Sri Lanka, Bangladesh, Japan, European Union, Denmark, Norway, among others, have welcomed the promulgation of the Constitution and have sent congratulatory remarks to all Nepalis. Even, Bhutanese PM Tshering Tobgey congratulated Nepali people on the promulgation of the new constitution with wishes to find a path to lasting peace and sustainability (Republica, 2015).

\section{Impacts of Transit Warfare}

Tarai-Madhes centric leaders of the Nepali Congress, UML, Maoists and RPP-Nepal heartily welcomed the New Constitution. However, 10 percent of the small Tarai-Madhes-based cultural parties in CA II rejected the proclamation of the new constitution, keeping themselves under the umbrella of Indian power, politics and property. These Madhesi groups turned down major parties' request to join in the constitution-making process, stating that the process was a mere formality. They made a demand to keep the southern belts of Jhapa, Morang and Sunsari districts as their Madhes province and constituencies based on population in the Tarai-Madhes. People of the number two Madhes province, ranging from Saptari to Parsa districts, suffered either from an indefinite general strike or curfews clamped on by local administration. More than 40 demonstrators and one-dozen security forces, including a Senior Superintendent of Police, have already lost their lives in a two-month period of protest.

However, the same Tarai-Madhes parties casted their votes in favor of Sushil Koirala, president, Nepali Congress during Prime Minister's election on October 11 under the same new constitution. The people from the Tarai-Madhes ask. Why did you boycott the CA II's constitution-making process? What did you 
participate on the PM's election? Who is "Rae"? Why are you behind "Rae”? etc. Tarai-Madhes people frustrated a lot while their leaders went to Indian Embassy in Kathmandu in the evening of October 10 and followed ambassador's directive.

Because of wrong or Goebbels' trend reporting of Ranjit Rae and the RAW, India initiated its imposition of transit blockade in all custom checkpoints, claiming that there was a security issue. India listens and supports the one-tenth percent of elected representatives' voices of Tarai-Madhes in the CA II, turning deaf-ear to uplift the blockade on Hindu's greatest festivals.

Nepal suffers a lot due to this transit blockade. Moreover, India further restricted import of gasoline products in Nepal. Even Indian Embassy in Kathmandu asked Nepal Oil Corporation (NOC) to produce petroleum products (Kathmandu Post, 2015). The NOC has received written requests for gasoline from 16 diplomatic missions in Kathmandu (Ibid). Due to the acute scarcity of gasoline, many of the hotels are already closed. Many hospitals are out of oxygen and other essential live-saving medicines. Rare ambulances or fire-brigades operate. The Government has imposed an odd-even system in vehicular movement. The Government is restricted from providing gasoline for private vehicles and motor bikes. Government vehicles are also restricted.

Dairy centers refused to collect milk, citing the lack of fuel and transport services to supply dairy products to major cities. Most of the schools are shut down. Even students who are studying in Kathmandu or other major cities are deprived from going to their houses on the greatest Hindu festival, Dashain, due to the lack of fuel for transportation. More than 400 vehicles are already experiencing arson by the Madhesi agitators. There are no counts of vandalized vehicles. The staffs of cargo vehicles stranded in queues for a long time are thrashed by the goons in India. Their belongings are looted, but security forces are biased against providing security for them. None of the international flights have received aviation turbine fuel from Nepal from September 29 onwards, but have been asked to fuel abroad. Operation of many flights are stopped. Tourists are either compelled to walk or leave Nepal. Nepal lacks livelihood and essential supplies. Tension between Pahade ${ }^{\text {viii }}$ and Madhesis ${ }^{\text {ix }}$ may erupt. It is to be noted that this is what would happen as communal violence erupts if Nepal should survive in an Indian-controlled economy.

Such crises had long been prepared for by Shyam Saran, former Indian ambassador to Nepal. He split a few ambitious and selfish-centered Madhesi leaders and asked them to function as cultural parties. Huge minds, muscles and moneys were invested for such fissions. The cultural groups were established to enhance India's bargaining power on the course to control Nepal's natural resources and to reestablish Nepal as a Hindu state. The 2007 Madhes movement erupted immediately after that while 2,280,000 people received citizenship certificates in Tarai-Madhes. Reports say that many of Nepali citizens' holders are citizens of India too.

On October 6, 2015, the European Union Delegation, the Heads of Mission of Denmark, Finland, France, Germany, the UK, and the Heads of Mission of Norway and Switzerland in Nepal pledged their support and encouragement for resolving the current troubles affecting the supply and distribution of Published by SCHOLINK INC. 
humanitarian supplies. The press statement reads, "The lack of basic goods is taking a heavy toll on the economy of Nepal, where recent earthquakes have pushed an additional 3.5 percent of the population under the poverty line, according to the estimates of the Post-Disaster Needs Assessment” (Republica, 2015). Finance Minister Dr. Ram Saran Mahat also spoke against the humanitarian crisis and asked China to open its many customs checkpoints (Himalayan Times, 2015).

UNICEF chief warned of humanitarian crisis in Nepal (Press Trust of India, 2015). Producing six-page urgent appeal, the National Human Rights Commission in Nepal has drawn the attention of the international community, the government and agitating parties on the serious humanitarian crisis occurring in Nepal. The rights body sent official letters Asian-Pacific Forum of National Human Rights Institutions, International Coordinating Committee for National Human Rights Institutions, (ICC) and UN Office of the High Commissioner for Human Rights (NHRC, 2015). Hospitals have stopped normal operations in the lack of medicines and oxygen gas. No gasoline is being provided to public and private vehicles except security officials. Only emergency flights are operating.

Upset, India put forwarded seven amendments (The Indian Express, 2015) to a new constitution to make Nepal acceptable to the agitating Madhesi groups. Some of the most important amendments to the New Constitution, recommended by India, are: to re-insert the right for Madhesi to participate in state structures on the principles of proportional inclusion; to stipulate that citizens by descent can hold high-ranking government posts ${ }^{\mathrm{x}}$ expanded to include those, like many Madhesis, who have acquired citizenship by birth or naturalization; foreign women married to Nepali citizens may acquire naturalized citizenship, and to be provided for in a federal law; Madhesi representation in National Assembly to be based on population of the Provinces; Timeframe for delineation of constituencies to be 10 years rather than the 20-year period laid out in the latest version of the Constitution. The disputed Kanchanpur, Kailali, Sunsari, Jhapa and Morang districts are homes to large populations of Madhesis and they should be included in the Madhes province (Kashmir, 2015). While these amendments received many comments, even in India, Spokesperson Vikas Swarup of the Ministry of External Affairs, New Delhi reacted by saying the report was incorrect (The Hindu, 2015).

Socialist leader Ashok Rai publicly stated that India has supported their agendas (Kathmandu Post, 2015). Uprendra Yadav stated that the 7-point demands are not of the United Democratic Madhesis Front (UDMF) (Himalayan Times, 2015), and Laxman Lal Karna said that the 7-point proposal was put forward by the Madhesi parties (The Himalayan Times, 2015). Thus, even agitating Madhesi groups are not happy with the proposal put forwarded by India.

India stated that majority of the population in Jhapa, Morang and Sunsari districts are Madhesis, but India is wrong as there are 55.5 percent population ${ }^{\mathrm{xi}}$ Pahade including Bahun, Chhetri, Ethnicity and Dalit. India was wrong for two reasons: first, they twisted the real data to fulfill their myopic interests against Nepal and second, they relied more on information provided by their own biased sources, i.e., Ranjit Rae and Tarai-Madhes leaders.

After promulgation of the constitution, a few of the Indian newspapers adopted the Goebbels' trend to 273

Published by SCHOLINK INC. 
defame provisions of Nepalese citizenship as incorporated into the new constitution. Such journalists often said, "Madhesi and Janajati are non-inclusive or fall in the category of naturalized citizens". Others say, "Children of Nepalese woman cannot enjoy citizen status unless the husband accepts Nepalese citizenship...” They deliver misinformation owing to bias in nature, loathe to admit rights and too lazy to attain real truth (The Times of India, 2015).

These are complete fictions regarding Nepalese citizens. Article 10.1 of the constitution writes, "No Nepali citizen shall be denied the right to acquire citizenship". Article 11.3 says, "A child of a citizen who has acquired citizenship of Nepal by birth before the commencement ... shall be entitled to Nepali citizenship...” Article 11.4 says, "Every child found in Nepal whereabouts of whose paternity and maternity is not known shall, until the mother or father is traced, be deemed a citizen of Nepal by descent”. Article 11.5 mentions, “A person born to a Nepali citizen mother and having his/her domicile in Nepal, but whose father is not traced, shall be conferred the Nepali citizenship by descent".

Articles 5 to 11 in Part II of the Constitution of India addressed the previsions of citizenship. It mentioned several fundamental rights for persons who migrated to India from Pakistan and India to Pakistan, persons of Indian origin residing outside India, acquiring citizenship of a foreign State, continuing the rights of citizenship and parliament to regulate the right of citizenship by law (The Constitution of India, 2007). Nepalese law does not have dual citizenship as does India. India does not have a provision to receive citizenship certificate for third gender or transgender rights, but Nepal has, "The person who is entitled to citizenship of Nepal by descent may obtain the citizenship certificate of Nepal from name of his/her mother or father along with gender identity” under article 12. Nepal's Article 11.7 “... if his/her father and mother both are the citizen of Nepal at the time of acquisition of the citizenship, he/she, if born in Nepal, may acquire citizenship by descent”, but such provisions have not been incorporated in India's own Constitution. Besides, India wants to extend its influential political role for former Princess Himani Shah, as she is the daughter of India.

The present ruling Government of India should also remember how they reacted in 2004 when Indian National Congress became the largest party in the Lok Sabha and Congress tried to make Sonia Gandhi Prime Minister of India. Sonia was rejected on the basis of her foreign origins (Hasan, 2004). There was an allegation that she had not renounced her Italian Citizenship. The current Foreign Minister, Sushma Swaraj, provocatively said she would shave her head and renounce politics if Sonia Gandhi became Prime Minister (Vembu, 2012). She had challenged this because of Sonia's citizenship status. If the BJP leaders read their own history, they will respect Nepal's new constitution and citizenship provisions.

It is to be remarked that the Nepalese Constitution is more progressive on minority rights, third gender rights, women's rights, inclusive rights and electoral rights than any Constitution in this region of Asia. The new constitution ensures full fundamental rights to all. Nepal's Constitution assures both electoral rights: first-past-the-post system as well as proportional representation unlike the first-past-the-post system alone in India. Nepal's constitution guarantees 33 percent reservation for women ${ }^{\mathrm{xii}}$, but India 
does not. Further, it is an open document which can be amended any time. Indeed, Nepal's constitution is a far more progressive, inclusive, participatory and gender and human rights friendly than India's. Thus, when India expresses dissatisfaction over Nepal's liberal constitution, they must realize that the same fundamental rights shall be demanded by the disadvantaged, marginalized and vulnerable groups residing across India.

\subsection{Protest against Warfare}

Student organizations affiliated with ruling parties such as Nepali Congress and CPN (UML), as well as the main opposition party UCPN-Maoist, staged protest rallies against the blockade in Kathmandu, Gulariya and several parts of the country. Hundreds of local people near Bhairahawa's custom checkpoint chased away the agitators who were sitting on the Nepo-India border to obstruct the Sunauli border point. Local people at Buddha Chowk in Bhairahawa burnt the effigies of Madhesi parties' leaders. Two agitating leaders, namely Upendra Yadav and Rajendra Mahato, were termed as the compradors of India. The protestors of Dhangadi in Kailali district claimed, "India never wants to see a peaceful and prosperous Nepal” (Kathmandu Post, 2015). People staged protest against India’s blockade in Jumla, Kanchanpur, Rupendehi, Nawalparasi, Kaski, Syangja, Lamjung, Palpa, Gulmi, Itahari and others in Nepal and burned the effigies of PM Modi and Indian flags ${ }^{\text {xiii }}$. The Nationalist Civil Forum staged a demonstration against the blockade in Kakarvita custom in Jhapa district on September 28, 2015. The protestors chanted anti-India and anti-Modi slogans. Rae warned that the supplies of goods and petroleum products may further be delayed if anti-Indian protests are staged and anti-Indian sentiments cannot be stopped (Kathmandu Post, 2015). But, angry masses would never care for his warning.

Similarly, cable TV operators cut off all Indian channels indefinitely, starting on September 29, as a symbolic protest against India’s blockade (India-Forums, 2015).

India’s CPI-Marxist slams India’s Modi government for “arrogant intervention” in Nepal (OneIndia, 2015). CPI-Marxists called upon the Central Government to ensure country-to-country and people-to-people relations between India and Nepal. CPI-Marxist General Secretary Sitaram Yechuri said, "the constitution was an internal matter of Nepal and that there is no point in taking an interventionist approach to a constitution that has been adopted by a majority” (Kathmandu Post, 2015). "Indian position to Nepal is unfortunate", stated the Polite-bureau meeting of the CPI-Marxist. CPI-M further stated that Modi and the BJP were willing to harm relations with Nepal for the sake of winning support of the Madhesis who have a substantial transborder presence in the neighboring areas of Bihar, keeping in mind the assembly elections there (Kathmandu Post, 2015). Modi wants to receive Madhesis votes in Bihar" (The Statesman, 2015). However, PM Modi suffered a heavy defeat with only 58 of the 243 available seats, in the elections in Bihar in early November (BBC, 2015).

Main opposition Indian National Congress Spokesperson Pramod Tiwari said, "Indian National Congress expresses deep concern over the recent developments and statements questioning the time honored Indo-Nepalese relationship with little initiative being seen on part of Government of India 
towards corrective action” (Republica, 2015). The Indian Congress expressed deep concern over India's ties with Nepal amidst growing unease after framing its Constitution for the crisis could compel Nepal to drift towards China (The Economic Times, 2015).

On November 4, 2015, responding in the 23rd Universal Periodic Review (UPR) session on UN Human Rights Council meeting in Geneva Deputy Prime Minister and Foreign Minister Kamal Thapa said, "Lives and livelihood of the entire population have been adversely affected; schools and hospitals have also had to bear the brunt of the current circumstances exposing millions of children, elderly and sick persons to greater risks and vulnerabilities; the future of our children is at stake; our regional and international trade have been constrained; our industries are on the verge of collapse, the tourism sector has been hit hard; and our economy has suffered a huge setback". Thapa further said, "If the current situation is not checked, the country is likely to experience an unjust and severe humanitarian crisis"xiv . Thus, Nepal's blockade issue is internationalized and most of the nation-states in the UN supported Nepal and Nepali people.

\subsection{Backdrop of Warfare}

Tarai-Madhes have put forward four-point proposals to end the impasse. They seek to amend the constitution to ensure proportional representation of underprivileged groups; revise constitutional provision to redraw electoral constituencies following population basis; revisit the delineation of provinces and initiate dialogue with disgruntled parties (Kathmandu Post, 2015). These demands are just a short-form of what the Ministry of External Affairs, Government of India accelerated as 7-point amendments. Some background information on these measures is given below.

First, Nepalese mainstream parties in the Constituent Assembly II such as Nepali Congress, CPN (UML), UCPN-Maoist and Madhesi People’s Rights Forum (Democratic) struck a historical 16-point agreement at the time of post-earthquake, on June 8, 2015. The leaders agreed to promulgate a constitution with an eight-province federal structure, delineating the boundaries of federal provinces through a Federal Commission, with the name of the each federal state to be determined by two-thirds of the State Assembly (Setopati, 2015). However, India stated its reservations on the agreement and invited former PM Prachanda in mid-July and former PM Sher Bahadur Deuba at the end of July, 2015. India wanted to know more regarding the details of the federalism working modality. India expressed its dissatisfaction, especially regarding demarcation in the federal provinces (Karki, 2015) and provision of Hindu state. It is learnt that both leaders agreed with "Nepal as a Hindu state". As the Constitution incorporated secularism, PM Modi adopted an offensive strategy against Nepal. On the other, India did not invite to the UML party.

However, India did not receive full assurance from Prachand and Deuba to make "One Province" in plain areas of Tarai-Madhes. Similarly, India failed to distract the relations between Prachanda and incumbent Prime Minister K P Oli. History has been a witness that India succeeded in adopting a "divide and rule" (philosophy) among the communist parties in Nepal. Close working relations between UML and Maoists made India still unhappier and that further tightened conspiracy ties against 
Nepal.

While India failed to convince Pranchanda and Deuba on Madhesi groups, India made a strong bond among United Democratic Madhesis Front or $\mathrm{UDMF}^{\mathrm{xv}}$ to counter a great majority of the populace. However, this bond is very weak in terms of their representation in the Constitution Assembly, influence of politico-ideology and their strategic dimensions. The UDMF represents just 34 (5.7\%) (Nepal Research, 2015) of CA II members out of 598. Moreover, only 8 members were elected from first-past-the-post and the remaining members were selected from proportional representation. Human rights worker Subodh Pyakurel said, "Let me tell you that those who are creating a furor in the name of Madhesis are the same individuals who were defeated by the voters in the past CA II elections. They ran away from the Constituent Assembly, but did not resign” (Pyakurel, 2015). After being defeated by the CA II elections, Rajendra Mahato stated that it was not his defeat, but “is India’s defeat” (Ibid).

India took the side of such poor and weak cultural groups who have minimal effect in Nepal's political, social and cultural arenas due to their low impact on people's representation, population diversity and geography, but a great majority of them are Hindu. This is a great shame to India as it provides ethical, monetary, strategical and religious support to Madhesi factions, disrespecting democratic values. The minority never rules a great majority of people. "Might is right” has been rejected, even in authority regimes in the present world.

UML leader Pradip Gyawali, who went India as a special envoy ${ }^{\text {xvi }}$ on behalf of K P Oli, said "Indians can fulfill their vested zest and zeal from the resource of rivers if Morang-Sunsari be kept in province no. 2...” (Nepal, 2015) The concept of “One Tarai Madhes” Province did not come from Nepal, but for harnessing hydropower and water resources projects for India with minimum obstacles. India wants to control all natural resources of Nepal in the name of security and strategic interest. This policy is an open secret. Nepalese leaders have been afraid to provide autonomous “One Madhes One Pradesh” since they fear possible secession and formation of a separate nation-state or merger into an Indian state: Bihar and Uttar Pradesh. That is why prominent leaders are reluctant to demarcate the boundaries of Morang, Sunsari and Jhapa into a no. 2 federal province. The one province demand of Madhesi people has been voiced by the new citizens of Nepal, not by older ones. The Madhesi who have been living in Tarai-Madhes for generations want to live with unity in diversity, including hills and mountains.

Second, the promulgation of a new constitution caused a backyard of instability in Nepal, stating political and security implications. But, the blockade had been planned for a long time. There has been a huge discrepancy between what India says and does (Nepal Foreign Affairs, 2015). One month ago (August 30), regarding the view point of Madhesi parties, former President of the BJP and present Union Home Minister Raj Nath Singh publicly said, "Although the Madhesi problem is an internal issue of Nepal, the Indian government will protect the interests of one-crore Indians living there" (Srivastava, 2015). He further said, "Madhesis are Indians who had migrated to Nepal years ago. While many have received Nepali citizenship, the majority of them are still without a nationality” (Ibid). The statement itself proves what India thinks and perceives regarding Madhes who are citizen of Nepal. The 
truth is that anybody can have a citizenship certificate from the concerned district headquarters, CDO office.

Srivastava writes, "The Madhesis allegedly said that several political and militant organizations have been targeting them and inflicting atrocities to force them to leave Nepal. However, the BJP has been supporting the Madhesis for a long time”. Even the BJP members of parliament have accused their leaders of being responsible for fishing in muddy water in the name of Nepal's constitution-making. He further said, "Yogi Adityanath, BJP MP from Gorakhpur and Mahant of Gorakshnath Temple, has often been accused of providing logistic support to the movement of the Madhesis against the Nepal government” (Ibid).

Third, senior BJP leaders have a clear understanding that Madhesis are predominantly Hindu. However, article 4 of the new constitution has mentioned a secular state. The same article has further mentioned the purpose of it stating ... “'secular' means protection of religion and culture being practiced since ancient times and religious and cultural freedom”. It is to be understood that most of the prominent leaders are Hindu, but largely influenced by mind and money of Christian states. The Christianity-influential leaders neglect the Hindu religion. The Hindu Gurus and leaders encourage their activists to initiate transit warfare opposing such trends. More than 80 percent of the people in the incumbent Legislative-Parliament are Hindu.

Fourth, the frustration of India was further aggravated while two mainstream communist parties ${ }^{\mathrm{xvi}}$ in the legislative-parliament improved their relationship for the sake of communist coalition Government. India's RAW and bureaucrats invested huge sums of money, muscle and mafia to "split and rule" the communists, but they failed unlike in the past. They have a fear that Indian communists (revolutionary and liberal democrat) may learn a lesson from Nepal and their united strength shall aggravate the political situation there. They have not forgotten the fact that "large numbers of sophisticated and modern weapons reached communist revolutionaries in India” from Nepal's rebels. The RAW succeeded in weakening the Maoist party, splitting them three times in the past. However, they failed to widen the gaps between two major community parties on this occasion. RAW used its final weapon, ousting former PM Dr. Baburam Bhattarai from the UCPN-Maoist (Nepali Times, 2015). Baburam Bhattarai wishes to be a hero in the Madhes movement (Himalayan Times, 2015). Therefore, he gave a resignation on September 26, 2015 on the whisper of India. Bhattarai who spent more than a dozen years studying on scholarship in India is known as a permanent dissident of the UCPN (Maoist).

Bhattarai's resignation shall be a suicidal decision this time as Bhattarai has shallow influence inside the party, parliament and people. Bhattarai was chased away from Janakpur on September 29 by Madhesi youths. His aide-de-camp, Ram Chandra Jha and Ram Kumar Sharma, were beaten (Himalayan Times, 2015). India has forwarded Bhattarai as an alternative candidate of the PM. This is just a daydream as anti-Indian sentiments are intensifying in all professions across Nepal for the first time in the history. 
Fifth, addressing a Conference on Cooperative Development, Peace and Security in South and Central Asia, Indian President Pranab Mukherjee gave top priority to South Asian Neighbors as Indispensable partners for shared prosperity and security. He articulated a desire to pursue a policy of three Cs: greater connectivity, closer cooperation and broader contacts to promote closer ties in the region ${ }^{\text {xviii }}$. Theoretically, these are excellent statements for sovereignty, territorial integrity, non-aggression and peaceful co-existence.

What are the practical stands of India to implement these Panchsheel principles? Speaking and practice of it are two different dimensions. The President also knows that India continues transit warfare by blocking vehicles entering Nepal, but time and again says, "This is not a transit blockade, but supporting agitating Madhesi seeking security to them”. Hundreds of loaded vehicles are stranded more than $100 \mathrm{~km}$ in distance from the custom checkpoints. What a shame! What true-liars! A friend can be changed, but neighbors never.

Sixth, there were a total of 116 seats from Tarai-Madhes out of 240 First-Past-The-Post (FPTP) CA II elections in 2013, but only 11 (9\%) of the representatives boycotted the constitution-making and signature on it in September 2015. Even India disrespected 90 percent CA members' signatures in the New Constitution. India forgot its own history of Constitution-making where a total of 67 percent (just two-thirds) of CA members signed the Constitution in January 1950. In response to the British government on the drafting of Constitution by the CA, Jawaharlal Nehru responded, "We have decided on how our Constitution is to be drafted" (Pyakurel, 2015). You must be aware of how you have been treating conflicted, sandwiched people at Jammu and Kashmir.

Although, Nepal is weak, small and poor, India can learn a lot from Nepal's democracy practices, human rights works and human security attempts. Nepal's human rights stalwart Professor Kapil Shrestha said, "India shall learn a lot on moral values, norms and principles of democracy and human rights from the newly established democratic country Nepal”xix . None of the civilized governments introduce hypocrisy in the name of democracy. The imposition of transit warfare is the principal example of "demon" and "crazy", deriving from democracy. Nepali is afraid of being Bhutanization and Bhutanization may turn to the process of Sikkimization.

Seventh, India initiated a blockade in the period of Nepal being totally blocked after the devastating April earthquake, while most of the custom checkpoints with China were blocked. Nepali Congress leader Bimalendra Nidhi, Physical Infrastructure Minister who represents the Central Tarai-Madhes, ignored removing the debris from the blocked road of Tatopani and Rasuwa-Kerung. Nidhi did not release money to open the roads following a conspiracy theory under the camouflage of India. If both Chinese custom checkpoints were operating, India would not dare to impose such a tough transit blockade.

Eight, we should not just blame India alone. The existing mainstream parties took huge benefit from the course of their formation and growth and protection. India is a home ground of the Nepali Congress. The Nepali Congress was established on Indian soil, grown up by the support of India and taking shelter in India. The Nepali Congress is silent because of its past connections, affiliations, stands to 
deliver natural resources, ideology (protect a few elites and rule to the great majority weak and poor, similar to bourgeois controls to proletariat) and current activities. The outgoing Prime Minister and other influential members of the Nepali Congress have ignored bringing gasoline products from China. Despite a huge public outcry to resolve the impasse, Nepali Congress leaders have turned deaf ears. They have a fear that they will never be appointed as ministers and other positions or step-down positions they are now acquiring, once they act or speak against India. Monetary support to them is also a great asset.

Former PM Sushil Koirala instructed all concerned institutions and actors to open Nepo-China transit as soon as possible (Kantipur, 2015), but it could not go beyond lip-service. Despite repeatedly asking "what humanitarian and commodity supports you are looking for from China, please tell us" by Chinese authorities, Nepal has failed to put forward a concrete proposal. Besides, Nepal's Ambassador in New Delhi, Deep Kumar Upadhyay, did not play a significant role to minimize the Nepo-India differences through diplomacy. He represents the Nepali Congress and Nepali Congress party, always encircled by vicious circle of confusion. That is repeated this time again.

Last, Nepal never tries to materialize the experiences learnt from past blockades by India. Jawaharlal Nehru initiated the soft blockade to Nepal in July 1950 for not entering third countries' goods into Nepal via India (Nepal, 2015). The then PM Indira Gandhi also introduced a transit blockade in 1970, demanding a revisit on the provisions of trade transit treaty. Moreover, PM Gandhi wanted to use indigenous people ${ }^{\mathrm{xx}}$ to intervene in Nepal. While late King Birendra brought weapons from China, India's PM Rajib Gandhi initiated a trade blockade showing trade and transit rights which expired in 1988. The blockade made a shortage of Indian imports such as gasoline, cooking oil, salt, food, and other essential commodities. However, the Panchayati Government brought the above-mentioned essential commodities by airlifting from Bangladesh, unlike the mute-procession of the former Nepali Congress-led Government. The principal cause was that India puts Nepal under its bigoted security umbrella. The blockade helped to restore multi-party democracy in Nepal in 1990 (Pathak, 2009). There is a passport system even in Pakistan and Bangladesh ${ }^{\mathrm{xxi}}$ and Indo-Pakistan and Indo-Bangladesh borders are sealed, but Nepo-India wipes out such restrictions. Even Nehru once said, “Aggression against Nepal is tantamount to aggression against India” (Nepali Times, 2000). Unlike restricted border in the world, Nepo-India has a porous border which covers more than 1,600 km; east, west and south.

India supported democratic movement in 1950 and restoring democracy in 1990 in Nepal. In return, Nepal has delivered most of the noted irrigation projects to them. Most such deliverances were signed to India by heads of the Nepali Congress Government, initiated by its founder B P Koirala. Most of the times, Nepali Congress has been heading Nepal after 1990xxii. Nepal has roji-roti-beti (Pathak, 2009) relations ${ }^{\text {xxiii }}$ with India. Even though, communists are closer to China. India has a fear that, once the Communist Government forms in Nepal with a strong tie between two major community forces ${ }^{\text {xxiv }}$, India's hegemony from Nepal would be gone. Present transit warfare is also a failed step to stop communists from capturing state power. From communist-led Government of Nepal, India felt insecure. 
However, both never try to resolve such fear and suspicion through mutual dialogue ${ }^{\mathrm{xxv}}$. The Government of Nepal has never dared to talk on this matter due to its inferior intricacy, but India by superior complexity.

Even the CPN (UML) was given a birth at Calcutta, India. The UCPN (Maoist) took all-round support from India while they were fighting against Nepal's constitutional forces and monarchy in the name of the People's War. However, UML and the Maoist did not bow their heads this time (2015) in the face of power, politics and property of India. None of the governments in Nepal in seven decades of democracy have been able to complete their full tenure successfully due to India's influential role in the Government of Nepal (Pathak, 2009).

None of the previous Nepalese Governments urged to talk on the revision of bilateral treaties and other matters with Indian Government. They followed what India instructed them. However, PM K P Oli warns India for not to interfere in Nepal's internal affairs (Zeenews, 2015). The internal matters shall be resolved through dialogue following win-win approach pursuing informal and formal talks, mediation and facilitation. Oli further said "India's blockade of transit routes is against the humanity, more inhuman than war” (Kantipur TV News, 2015). Oli firmly believes that trade blockade is extreme act of cruelty and crime against humanity.

\section{Conclusion}

The present crisis of transit warfare is the talk of the town, even in international communities. On October 8, 2015, the US Department of State advised its citizens to consider their plans to visit Nepal because of India's blockades (Kathmandu Post, 2015). Therefore, Nepal produces huge speculations, horizontally and vertically. First, the PM Modi led-government tries to keep all neighbors under its umbrella rather than pursuing sovereign equality, territorial integrity, non-intervention and aggression and mutual respect. Second, India disrespects rights of transit trade of landlocked countries, humanitarian law, human rights conventions and treaties and world trade organization. Third, India was trying to re-elect present President Ram Baran Yadav again or from Tarai-Madhes leader, fully aware of the fact that the next President shall be from Pahade community. Fourth, Nepal has a fear that the delineation of boundaries of Tarai-Madhes province based on the population may lead to succession of Nepal in the long run, sending more people from the neighboring Bihar and UP. Besides, the more representation of Madhesis in Nepal's state mechanism proliferates India's power bargaining for its vested interests.

Fifth, a large number of Nepali believe that Modi took retaliation as his visit to Janakpur ${ }^{\text {xxvi }}$, Lumbini $^{\text {xxvii }}$ and Muktinath ${ }^{\text {xxviii }}$ were cancelled. Those visits were scheduled in the last 18th SAARC summit held in Nepal in November 2014. Last, Modi was severely humiliated while Nepal's Legislative-Parliament raised a serious objection over the agreement of Lipu-Lekh Pass that was signed between India and China in May 2015. Nepal claims that Lipu-Lekh is a part of Nepal's territory and asked both of them to correct the pact immediately (The Economic Times, 2015). Modi seems very 
talented and clever, similar to late King Mahendra. He pursues Monroe Doctrine or Indira Gandhi's merger policy to Nepal (Upol, 2015). However, his bold decision and repetition of mistakes and wrongdoings may lead to a suicide similar to what Mahendra did in 1972.

CPN-UML Chairman K P Oli ${ }^{\text {xix }}$ has been elected as a new Prime Minister with 338 (56.5\%) votes from the Legislative Parliament on October 11, 2015. Oli defeated outgoing PM Sushil Koirala against 249 votes. Koirala violated the gentlemen agreement to support Oli for PM that had agreed in 16-point deal in June 2015 (Kathmandu Post, 2015). India dispatched former RAW Chief A B Mathur with 930 million Indian currency (Josse, 2015) to defeat the candidate of PM Oli. To plot Koirala's victory, a skull session (consultative meeting) was help among President Dr. Ram Baran Yadav, PM Sushil Koirala, former PM Sher Bahadur Deuba, Mathur and Ambassador Rae on October 10 (Ibid). Same night, Mathur and Rae invited Tarai-Madhes agitating leaders of the United Democratic Madhesis Front into the Indian Embassy. Rae, skipper of Tarai-Madhes agitation said, “India has been supporting your Tarai-Madhes agitation. You could not stay as neutral. The winning of Oli as a Prime Minister of Nepal is a defeat of India. You need to cast votes to Koirala. If you do not support him, we will uplift the blockade” (Ratopati, 2015). They voted in favor of Koirala, but he defeated with a huge margin. It is to be remarkable that the Front leaders boycotted the Constitution-making process in the CA II, but voted under the same Constitution. Thus, India has been providing moral, financial, technical and sending people to support Tarai-Madhes agitation.

India is alone in this South Asian region as its border directly and indirectly links with all member states of the SAARC. Except Bhutan, all neighboring countries such as Pakistan, Bangladesh, and Sri Lanka and among others have been competing "anonymity” relations with India as compared to peace, harmony and friendship. This happens while Indian Government tries to impose democratic oligarchy, security feudalism, capitalist socialism, justice anarchy, controlled friendship and authoritarian rule of law. Modi's intervention doctrine shall be failed. Modi is now and onwards moving towards plummeting popularity similar to the past Indian PMs who imposed unilateral blockade in Nepal.

After Pakistan, Nepal's transit warfare is India's biggest foreign policy failure (Bhushan, 2015). PM Oli told the Indian Ambassador to mind his own business. Prachanda says that Nepal is not India's yes-man. Sushil Koirala is suspicious of India (Ibid). On September 22, from the Tudikhel speech, Prachanda expressed his unhappiness with Modi's special envoy S. Jaishankar as Jaishankar humiliated and disrespected him (Dhakal, 2015). Does Nepal's special envoy visit in India disrespect any former PM of mainstream leader in such an ungrateful manner? The answer is no. Nepali Congress Prime Ministers never feel humiliation while an Indian ambassador directly holds a meeting with them, frequently without informing the Ministry of Foreign Affairs and without noticing protocol status. Can Nepal's ambassador residing in New Delhi enjoy such talk with the Prime Minister of India? No, never. It is very difficult to meet even with a concerned Minister at New Delhi, despite repeated requests by Nepal's ambassador. 
Nepal's mainstream leaders, despite the politico-ideological spectrum, are united against India's Constitutional amendments (Bhushan, 2015). Nepo-India relations should be redefined to safeguard both nation's interests. The Kathmandu elite should realize that Nepal needs to deal with a new agreement as per the wishes of people with India (Ibid). India should remember how Nepali people were recruited ${ }^{\mathrm{xxx}}$ in the past to sacrifice against the British for Indian people.

It is to be noted that whatever the major political changes including declaration of Republic Federal State in 2008 were taken place through the active role, participation and cooperation of people and Government of India. However, only difference between the past and present is that Nepali people of all diversities were along the path of India previously. But, incumbent Modi-led Government tries to support small groups of Madhesis now. Modi-led Government has two options: either be withdrawn transit blockade unilaterally or spoiled the age-old friendly and harmonious relations further between two neighbors. Despite severe humanitarian crisis, Nepal should compel to walk a path of self-reliant in future. Moreover, Nepal shall gradually improve alternative means of livelihood and other humanitarian needs opening the avenues of supply from China. India should pay a huge price of present transit warfare in the long run.

General people turn to China for its active role of "warm-friendship" in Nepal, ignoring generations-old cold-friendship diplomacy, silence-negotiation, sadistic policy and mute-procession. Continuing the silence may raise a security threat from Nepal for the secession of Tibet due to a 1,400 km long porous Nepo-China border. China's positive cooperation in Nepal may help to promote Panchasheel in this region. The need of SAARC is collapsed unless India abandons expansionist hegemony or China's active participation in the SAARC.

The present crisis of Nepal, rather than being home-grown, has been imported from India. All agitating Tarai-Madhes leaders accepted that they are being backed by India. That is why people of Nepal are pressing the Government not to bow down their heads in front of India. There is a huge voice to take stern action to Ambassador Rae against the Goebbels'-style reporting. The whipping up of anti-Indian sentiments shall only be stopped once India lifts up the transit blockade and makes a public apology ${ }^{\mathrm{xxxi}}$ in front of the Nepali people.

\section{References}

BBC. (November 8, 2015). India PM Narendra Modi in Bihar election Setback. London.

BBC. (September 24, 2015). Nepal constitution: New border protests block supplies from India. London. Bhaumik, S. (October 5, 2015). India needs no Monroe Doctrine. The Hindu. New Delhi. Bhushan, B. (September 23, 2015). India's spectacular policy failure in Nepal. Catchnews. CNN. (October 3, 2015). Nepal accuses India of "trade blockade" amid fuel crisis. Washington.

Dhakal, B. (September 29, 2015). Indian designs. Republica. Kathmandu.

Eherald post. (September 29, 2015). Obama expresses happiness for new constitution in Nepal. Retrieved from http://www.eheraldpost.com/en/obama-expresses-happiness-for-new-constitution- 
in-nepal/

Gautam, K. C. (September 28, 2015). Opinion: U.N.’s Mixed Messages on Nepal's Constitution. Inter Press Service News Agency.

Ghimire, Y. R. (November 3, 2015). In “shadow-boxing” between Nepal and India, China gains influence. The Indian Express. New Delhi.

Gurung, K. J. (n.d.). Indira Gandhilai Vedta (Meeting with India Gandhi). Nepal Weekly. Kathmandu.

Hasan, Z. (2004). Indian Elections 2004: A Setback for BJP’s Exclusive Agenda. New Delhi: Nehru University.

Himalayan Times. (September 21, 2015). Statute protested in Saptari, Mahottari. Kathmandu.

Himalayan Times. (September 24, 2015). 7-point proposal put forth by Madhesi parties: Laxman Lal Karna. Kathmandu.

Himalayan Times. (September 26, 2015). Upendra Yadav stresses on implementation of past pacts, says 7-point demand not of UDMF. Kathmandu.

Himalayan Times. (September 28, 2015). BRB keep to join Madhesis. Kathmandu.

Himalayan Times. (September 29, 2015). Baburam Bhattarai's stage set on fire, Ram Chandra Jha beaten up in Janakpur. Kathmandu.

Himalayan Times. (September 29, 2015). Mahat warns of humanitarian crisis. Kathmandu.

Himalayan Times. (September 29, 2015). New Constitution Welcomed. Kathmandu.

Himalayan Times. (September 30, 2015). Private vehicles barred from purchasing fuel. Kathmandu.

Himalayan Times. (October 4, 2015). Industries on the verge of collapse. Perspectives. Kathmandu.

India-Forums. (September 28, 2015). Nepal cable operators to stop broadcast of Indian channels. Indo Asian News Service.

Indian Express. (September 20, 2015). India asks Nepal to resolve differences via peaceful dialogue. New Delhi.

Josse, M. R. (October 14, 2015). Urgently needed: strategy to “contain” India. People's Review. Retrieved from http://www.peoplesreview.com.np/

Kantipur TV News. (November 6, 2015). Kathmandu.

Kantipur. (September 29, 2015). Chiniya Naka Khulaun Pahal (Initiation to Open China Transit Point). Kathmandu.

Karki, R. (October 3, 2015). India's Interest on Nepal's Federalism. Retrieved from http://nepalforeignaffairs.com/indias-interest-on-nepals-federalism/

Kashmir Monitor. (September 24, 2015). Make seven changes to your Constitution: India tells Nepal. Srinagar.

Kathmandu Post. (n.d.). 40 pc of hotels, restaurants shut. Kathmandu.

Kathmandu Post. (September 21, 2015). China congratulates Nepal on the promulgation of the constitution. Kathmandu.

Kathmandu Post. (September 28, 2015). Indian position on Nepal “unfortunate”: CPI (M). 284

Published by SCHOLINK INC. 
Kathmandu.

Kathmandu Post. (September 29, 2015). NC Madhes leaders table 4-pt suggestion. Kathmandu.

Kathmandu Post. (September 29, 2015). Protests rage across country against India's blockade. Kathmandu.

Kathmandu Post. (September 30, 2015). Delhi concerned over whipping up of anti-India sentiments. Kathmandu.

Kathmandu Post. (September 30, 2015). Xi: Respect another country’s sovereignty. Kathmandu.

Kathmandu Post. (October 5, 2015). India commits not to stop goods supply. Kathmandu.

Kathmandu Post. (October 7, 2015). Indian Embassy asks NOC for Oil. Kathmandu.

Kathmandu Post. (October 10, 2015). Border blockade: US warns visiting citizens. Kathmandu.

Kathmandu Post. (October 12, 2015). UML's Oli elected new PM. Kathmandu.

Kathmandu Post. (November 6, 2015). Stop bullying Nepal, CPI-M tells Modi. Kathmandu.

National Human Rights Commission. (November 8, 2015). National Human Rights Commissions’ Key Concerns and Urgent Appeal Regarding Humanitarian Crisis and Its Impact on Human Rights in Nepal. Kathmandu.

Nepal Foreign Affairs. (September 28, 2015). Commentary: Back off India. Retrieved from http://nepalforeignaffairs.com/ commentary-back-off-india/

Nepal Research. (October 4, 2015). Elections of 19 November 2013. Retrieved from http://www.nepalresearch.com/

Nepal. (October 4, 2015). Dakshin Dhakka (South Shaking). Kathmandu: Kantipur Publications.

Nepali Times. (August 2, 2000). The enigma of distance. Kathmandu.

Nepali Times. (September 20, 2015). People’s Constitution. Kathmandu.

Nepali Times. (September 26, 2015). Bhattarai quits Maoist party. Kathmandu.

Nepali Times. (October 3, 2015). Blockade lifted. Kathmandu.

OneIndia. (September 23, 2015). CPI (M) slams Modi govt for "arrogant intervention" in Nepal. Retrieved from http://www.oneindia.com/contact.html

Pathak, B. (2005). Politics of People's War and Human Rights in Nepal. Kathmandu: BIMIPA Publications.

Pathak, B. (May 23, 2009). Nepal-India Relations: Open Secret Diplomacy. Situation Update 84. Kathmandu: PCS Center.

Pathak, B. (September 28, 2014). India's Seven Freedom Doctrine to Nepal. Retrieved from http://www.e-ir.info/2014/09/28/indias-seven-freedoms-doctrine-to-nepal/

Press Trust of India. (November 7, 2015). UN warns of a crisis for Nepal's children. New Delhi.

Pyakurel, S. (September 28, 2015). 15 point open letter to Modi from an angry Nepali. Catch News.

Ratopati. (October 15, 2015). Bharatle Afulai Phasayeko Madhesi Morcha Netako Arop (Leader of Madhesi Front allegedly said India Deceived US). Retrieved from http://www.ratopati.com/news/8899/ 
Republica. (September 16, 2015). UK, Germany, Russia welcome new constitution. Kathmandu.

Republica. (September 23, 2015). Germany, France, US greet new constitution UN “acknowledges”. Kathmandu.

Republica. (September 26, 2015). Narendra Modi's effigy burned in Dhangadhi. Kathmandu.

Republica. (September 28, 2015). DPM Singh holds meeting with Bhutanese PM. Kathmandu.

Republica. (October 6, 2015). EU countries to distribute humanitarian supplies in Nepal. Kathmandu.

Republica. (October 6, 2015). Indian Congress urges PM Modi to restore India-Nepal ties. Kathmandu.

Setopati. (June 9, 2015). Parties sign 16-point agreement to draft constitution (With full text of agreement in Nepali). Retrieved from http://setopati.net/politics/6953/Parties-sign-16-pointagreement-to-draft-constitution-(With-full-text-of-agreement-in-Nepali-)/

Srivastava, P. (August 30, 2015). Home Ministry fears for Madhesis in Nepal after alleged atrocities against the community. Mailonline India.

The Constitution of India. (December 1, 2007). Ministry of Law and Justice. Government of India.

The Economic Times. (June 9, 2015). Nepal objects to India-China trade pact via Lipu-Lekh Pass. New Delhi.

The Economic Times. (October 5, 2015). Congress urges PM Narendra Modi to restore India-Nepal ties amidst crisis. New Delhi.

The Hindu. (September 26, 2015). Vikas Swarup to be new spokesperson of External Affairs Ministry. New Delhi.

The Indian Express. (September 24, 2015). Make seven changes to your Constitution: India tells Nepal. New Delhi.

The Kathmandu Post. (September 27, 2015). India has supported our agitation: Leader Rai. Kathmandu.

The New York Times. (September 27, 2015). Xi Jinping of China Calls for Cooperation and Partnerships in U.N. Speech. New York.

The Statesman. November 3, 2015. Nepal blockade linked to Bihar votes, says Katju. New Delhi.

The Times of India. (September 24, 2015). Nepal messed up its constitution, India messed up its handling of Nepal. New Delhi.

Upol, A. K. (November 3, 2015). Bad Blood: India’s Blockade of Nepal. International Digest Policy.

US Department of State. (September 21, 2015). Daily Press Briefing. Washington.

Vembu. (June 30, 2012). Sonia-as-PM in 2004: Has Kalam backtracked or is Swamy wrong? Firstpost.

\section{Notes}

i "Oli” is a surname of K P Sharma (or K P Sharma Oli) who is a Chairperson of the Communist Party of Nepal (United Marxist-Leninist). 
${ }^{\text {ii }}$ President Xi Jinping of China addresses during the 70th session of the UN General Assembly, UN Headquarters in New York.

iii 10 percent Madhesi dwellers at the CA II.

iv Ignoring great majority population.

v The Government of Nepal Act 1948, the Interim Government of Nepal Act 1951, The Constitution of Kingdom of Nepal 1959, The Constitution of Nepal 1962, The Constitution of Kingdom of Nepal 1990 and the Interim Constitution of Nepal 2007.

${ }^{v i}$ Constitution of Nepal 2015.

vii Some of the major events those led to promulgate a republic constitution were: last monarch reinstated parliament on April 24, 2006; 25-point code of conduct of truce on May 26, 2006; King's power scraped by parliament on June 10, 2006; Comprehensive Peace Agreement on November 21, 2006; Nepali Congress decided to go into Republican State on September 26, 2007; the CA I elections held in April 2008; the first meeting of the CA I declared Nepal a Republic on May 28, 2008; the CA I dissolved on May 27, 2012; while Bhattarai-led Government failed to hold CA II elections, parties formed a neutral government under the Chief Justice on March 14, 2013; the CA II elections held in November 2013; NC, UML and UCNP-Maoist 16-point agreement on June 8, 2015; and a new Constitution promulgated on September 20, 2015.

viii Hill and Mountain dwellers.

${ }^{\text {ix }}$ Inhabitants of Tarai-Madhes, plain areas bordering with India.

${ }^{x}$ Namely, President, Vice-President, Prime Minister, Chief Justice, Speaker of Parliament, Chairperson of National Assembly, Head of Province, Chief Minister, Speaker of Provincial Assembly and Chief of Security Bodies.

${ }^{x i}$ Central Bureau of Statistics, Government of Nepal on September 30, 2015.

xii Article 84.8 under federal Parliament, "Notwithstanding anything contained elsewhere in this Article, women should account for at least one third of total members elected from each party in Federal Parliament. In case, one-third percentage of women are not elected while being elected under section (a) of clause (1), and section (a), clause (2) of Article 84, the party that fails to ensure one-third representation shall have to elect at least one-third of total numbers as woman in the Federal Parliament while electing members under section (b) of clause (1)".

xiii Nepalese Students burnt effigies of India PM Narendra Modi (Retrieved from https://www.youtube.com/watch?v=8N9dl7Dndns); Modi’s effigy burned in Nepal (Retrieved from https://www.youtube.com/watch?v=zcSs5_u6NDA); Indian PM Modi’s effigy burned at Dhangadhi in Nepal (Retrieved from https://www.youtube.com/watch?v=3nZiy-z0z0M).

xiv Opening Statement Delivered by Hon. Deputy Prime Minister and Minister for Foreign Affairs Kamal Thapa on November 4, 2015 at 23rd Session of Universal Periodic Review(UPR) Working Group of Human Rights Council in Geneva. 
${ }^{\mathrm{xv}}$ Federal Socialist Forum Nepal, Sadbhawana Party, Tarai-Madhes Loktantrik Party and Tarai-Madhes Sadbhawana Party).

xvi September 14 to 18, 2015.

xvii CPN (UML) and the UCPN (Maoist).

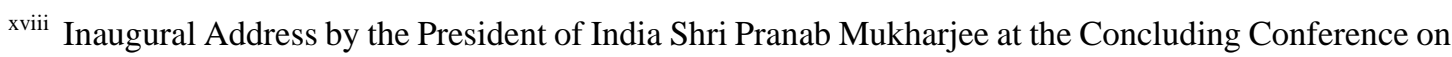
“Cooperative Development, Peace and Security in South Asia and Central Asia”. Retrieved from www.facebook.com/presidentofindiarb/posts/714585015308149

xix Personal communication on October 3, 2015 at park village resort, Kathmandu.

${ }^{\mathrm{xx}}$ Gurung, Limbu, Rai, Magar and so forth.

${ }^{x x i}$ Religious split occurred in India to Pakistan in 1947 and linguistic split to Bangladesh from Pakistan in 1971.

xxii That attains restoration of multi-party democracy.

xxiii Relation of employment, bread and daughter.

xxiv UML and the Maoists.

${ }^{x x v}$ Direct/indirect and formal/informal.

xxvi A birth place of Hindu goddesses Sita.

xxvii The birthplace of Lord Buddha.

xxviii Place of liberation (moksha) for both Hindus and Buddhists.

xxix 6th Prime Minister from the communist party and 4th from the UML.

xxx Gorkha Rifles Regiments and British Indian Army since 1815.

xxxi Opposition lawmaker Mani Shankar Aiyar said, “The best the rest of us could do is to apologize to the Nepalese for the atrocious behavior of our establishment and wish them all the best for a stable future”. Associated Press. Anti-India Anger in Nepal as Flow of Essential Supplies Dries Up. VOA (Voice of America). Washington. 